\title{
Economical and Environmental Friendly Methods for Separation of Oil from Mill Scale
}

\author{
Muhammad Shoukat Hussain ${ }^{\mathrm{a} *}$, Asra Shoukat ${ }^{\mathrm{b}}$, Hafiz Syed Umer Nasir ${ }^{\mathrm{b}}$ and Ammara Shoukat ${ }^{\mathrm{c}}$
}

${ }^{a}$ Research and Development, Process Laboratories, Pakistan Steel, Bin Qasim, Karachi, Pakistan.

${ }^{b}$ Dawood University of Engineering and Technology, Department of Metallurgy and Materials Engineering, Karachi, Pakistan.

${ }^{\mathrm{c}}$ NED University of Engineering and Technology, Department of Electrical Engineering, Karachi, Pakistan.

* Correspondence: shoukatchemist@gmail.com; Tel.: +92-3332422406

\begin{abstract}
Mill scale is the by-product of iron and steel industry. It can be recycled via sinter plant or solid as sinter feed materials. 85 to $90 \%$ of the constituent particles are more than 0.008 inches. The iron content is near around $70 \%$, with a very small amount of alkaline compounds and non-ferrous metals. Mill scale is polluted and contaminated with lubricants, oils and greases from the equipment. In this experiment for recovering of oil from mill scale, it is treated with three different methods. Then all methods were compared according to the ability of oil elimination and iron recovered. After washing and boiling with surfactants, large amount of polluted waste water becomes a problem for environment so this wastewater was utilized for making of Microbial Fuel Cells (MFCs), production of electricity in MFC depends on the biodegradation of organic materials, so different waste were added in wastewater for making MFC. The remaining of MFC was converted in bioethanol, biodiesel and biofertilizer. So this research is economical and environmentally friendly and fulfilled the important aspect of green environment with zero waste. It will be a mile stone in the research of metallurgy, environmental engineering, recycling technology and zero waste management.
\end{abstract}

Keywords: Mill scale; by-product; economical method; environment friendly; Zero waste.

\section{Background of the Study}

At some stage in the processing of steel in steel mills, iron oxides will appear on the surface of the metal. These oxides, identified as mill scale, these occur during the process of reheating, continuous casting and hot rolling operations. Mill scale is a precious waste material because it contains $65-70 \%$ iron [1]. Mill scale is a very attractive industrial waste due to its richness in iron. In various iron and steel making processes, near about $500 \mathrm{~kg} /$ ton of solid wastes of various natures are produced and generated [2]. Mill scale is during the metallurgical process in the steel making process and mostly during the processes which taken place after the blast furnace [3]. 
The process which is used to form the final steel products usually involve lubricants both in the process of manufacturing the final product and used in the equipment exposed to hot steel during the preparation of the final steel products. So, oil contamination of mill scale, which is an iron oxide by-product and formed during the steelmaking process [4; 5]. Economical and sociopolitical drivers are developing implementation of advanced thermal conversion technology like thermal plasma technology and these are probable to become commercially viable in the future [6]. This oil contaminated mill scale limits its recycle back into the steel making process because the heat involved liberates hydrocarbons and different oxides of hydrocarbons which pollute the air and do not permit operators to meet environmental quality demands [7]. Beside of this, if the waste mill scale is used for the sinter plant which are fed to blast furnaces, the contaminated oil the mill scale results in problems by fouling fan blades and filter bags and producing the excessive hydrocarbon emissions. The increasing amounts of mill scale in steel industry which cannot be used because of oil contamination which results both in higher disposal costs [8].

Mill scale waste can be treated and changed into valuable and important products like high purity iron as alternative used in low carbon steel, ductile iron production, and free cutting steel [9]. It is surprising in fact to realize that a usual steel mill produces from 100 to about 750 tons per day of mill scale, all of which is contaminated with hydrocarbon oils and sludge as shown in Figure 1. 


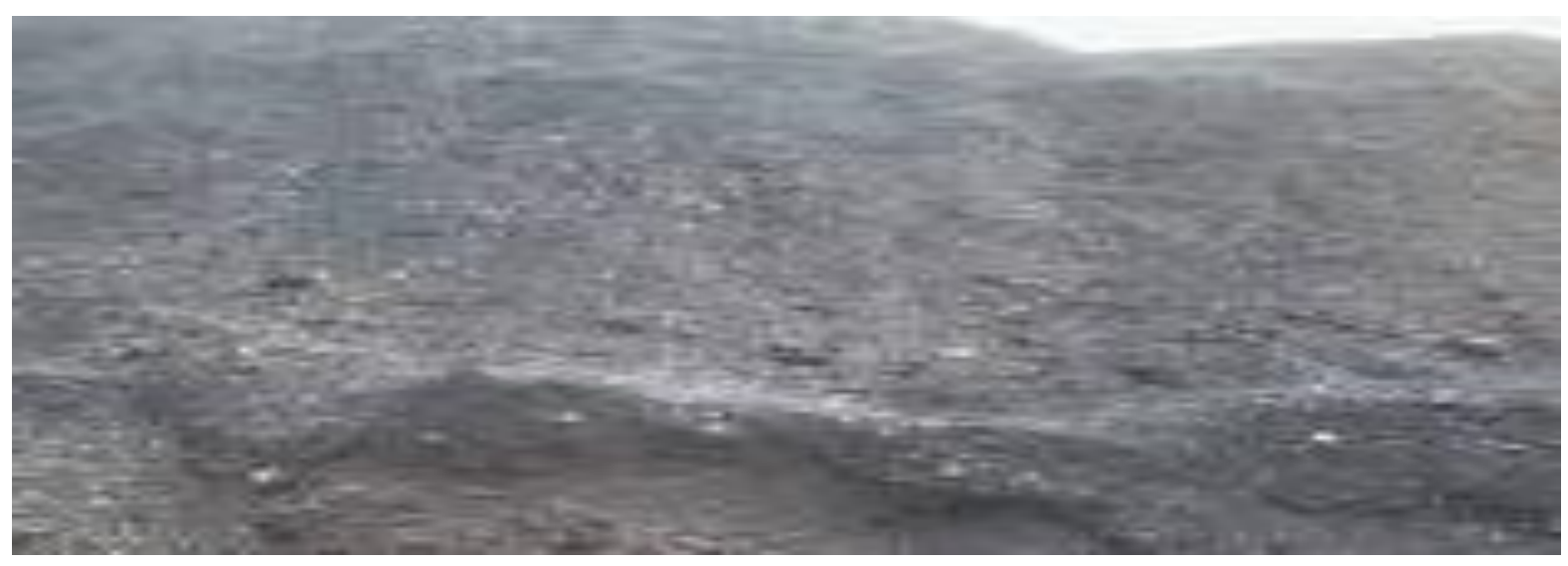

Figure 1. Mill scale in steel industry which is $4 \%$ of total production.

When the contamination of a mill scale increases $0.5 \%$ to $5 \%$ and above, this mill scale is unable for recycling for the sinter plant because of the problems caused by extreme hydrocarbon emissions [10]. The mill became the cause of blinding of filter bags, fouling of fan blades, and other problems. Different approaches have been utilized in the past for removing oil from mill scale included solvent extraction using a non-aqueous solvent in which the hydrocarbon oils were soluble or a hydrocarbon solvent, kiln processes which oxidized and vaporized the oil, thereby decreasing their content on the mill scale, and large concentrations of detergents and surfactants which were utilized for removing oil from the mill scale [11]. None of these techniques have been flourishing in commercial operation. Solvent extractions are costly and create toxic air pollution hazards and other pollution [12]. Heated kiln processes which oxidize and vaporize oily contaminants emit, emit large amount of hydrocarbon emissions and in the past this processes do not attain allowable air quality levels [13]. The detergent water creates foaming problems [14].

It is as a result an object of this research to give a process which will remove enough oil from mill scale to permit the recycle of this mill scale back into the steelmaking procedure without risk to the environment through large hydrocarbon emissions. It is also an objective of this research to get a de-oiling process for mill scale which will remove and recover oil from mill 
scale and provide a small oil bearing mill scale for recycling into the blast furnace or through the sinter plant which produces blast furnace feeds. It is an objective of this development to develop a procedure to de-oil mill scale, permit its recycle into the steelmaking process, and attain this in a shorter time scale. This also shall be completed without providing main impact on the environment. It is an additional object of this research to achieve the de-oiling of mill scale with a large energy slurry method whereby extremely concentrated iron oxide slurries are prepared by contaminated mill scale in water and then providing enough energy to remove contaminating oils from the mill scale and either dissolving, suspending, or emulsifying oil in the water used to make the slurry. It is possible to remove at least $90 \%$ of the oil initially contaminating an oily mill scale.

Treatment is consisted of following steps sintering, green balling, and high temperature kiln processing. Oil contaminated mill scales being processed in a washing drum containing the wash liquor contains various detergents with wash liquor at $\mathrm{pH}$ 12-14 [15]. During the process the solids are lifted by the use of blades on the washing drum, a device for displacing the wash liquor with water and a dewatering unit. Besides of above, different patents have been registered those have as their ability the treatment and recovery of iron from mill scale by recycling in the steel industries.

After washing large amount of detergent containing wastewater is obtained during the process of recovery of mill scale is a very serious environmental problem in recent years, resulting in large losses of endangering life and health. Detergents are acutely toxic to fish and other living things in concentrations between 0.4 and $40 \mathrm{mg} / 1$ but detergents in waters are typically degraded, and a maximum permissible concentration of $0.5 \mathrm{mg} / 1$ would probably be harmless so treatment of detergent water is necessary for the protection of our environment [16]. Due to the compensation of low cost, high efficiency and less secondary pollution, microbial 
remediation technology with mixing of canteen and garden waste is extensively used in the treatment of wastewater pollution [17]. After production bioelectricity remaining of MFC is a source of pollution, this mixture is treated by the production of bioethanol by fermentation, biodiesel by transesterification, biogas by decomposition of organic substance and production of biofertilizer.

\section{Study Area and Research Methodology}

\subsection{Research Design}

Different substances have been taken from various shops of the Pakistan Steel mill, mill scale is taken from water supply and treatment department, canteen waste from SMD canteen, waste fruit, leaf and flower were collected from green belt around road near operation building, waste Zinc galvanized metals and waste copper metal were taken from the scrap shop of Steel Making Department and Cold Rolling Mills scale (Pakistan Steel). All chemicals are used at Process Laboratories including $\mathrm{NaOH}, \mathrm{HNO}_{3}, \mathrm{KOH}, \mathrm{H}_{3} \mathrm{PO}_{4}$ for test of oil and iron are Merck grade.

\subsection{Research Materials}

\subsubsection{Collection of Mill Scale}

Iron mill scale was collected from water supply and treatment department of Pakistan steel near the operational building. The upper layer is collected which contain maximum mud and impurity for checking of maximum feasibility. $10 \mathrm{Kg}$ was taken for experimental works.

\subsubsection{Collection of Waste}

Canteen wastes were collected from SMD Canteen, waste fruits; leaf and flower were collected from trees near operation building. Waste Zinc galvanized metals and Copper metal were collected from CMD and SMD department of Pakistan Steel. 


\subsection{Pretreatment}

Mill scales were washed with water to separate mud, clothes, small wire, plastic and other undesirable materials. For this purpose mill scale $(5 \mathrm{Kg})$ were put in bucket of water, then all things were mixed, large mud or other breakable things were broken in small piece and undesired large things were separated with the help of sieve. Now the irons which were mixed with mud and oil were spread on the floor for drying, large contaminated particles were separated. After 3 days dried mill scale was collected and weigh $(4.2 \mathrm{Kg})$ for further experiment. For making of Microbial Fuel Cells waste fruit, leaf and flower were dried and grind $5 \mathrm{Kg}$ of powder of fruits by Black \& Decker (FX-350B) chopper, leaf and flowers were taken in the pot. Food wastes from canteen were taken just adding in wastewater of MFC before adding food waste was grind. After washing contaminated water and these wastes (canteen and garden waste) were mixed for making of MFC.

\subsection{Oil removing methods}

Washing with surfactants, direct heating and collection of oil in long pipe: Mill scale $(500 \mathrm{~g})$ and detergent $(10 \mathrm{~g})$ were mixed in water (2.5 liter) to continue stirring for 10 minutes. The mud and some oil were mixed with water of detergent, water was decanted carefully because iron particle were also poured out with water due to very small size. The decant water was filtered with help of fine silk clothes, in filtrate iron is also present, filtrates were again treated same treatment for maximum recovery of iron particles which were small in size. Now it was left for drying in the sunlight, mud and iron were separated by forming two layer, the upper layer was consist of mud while iron was in the lower layer. With help of fresh water and detergent this whole processes were repeated three times. During washing mud and water soluble impurities was removed from mill scale, but oil was not completely removed from mill scale so it need 
further treatment. Same process was repeated, but this time Mill scale (500 g) and detergent (10 g) were mixed in water (2.5 liter) then heating on a gas stove with continue stirring for 30 minutes. During heating make it confirm that mill scale was dipped in water of detergent to avoid and reduce the chance of the escaping of oil vapor in the atmosphere and with continuous stirring as shown in Figure 2. This process was repeated three times, every time fresh water and detergent was taken.

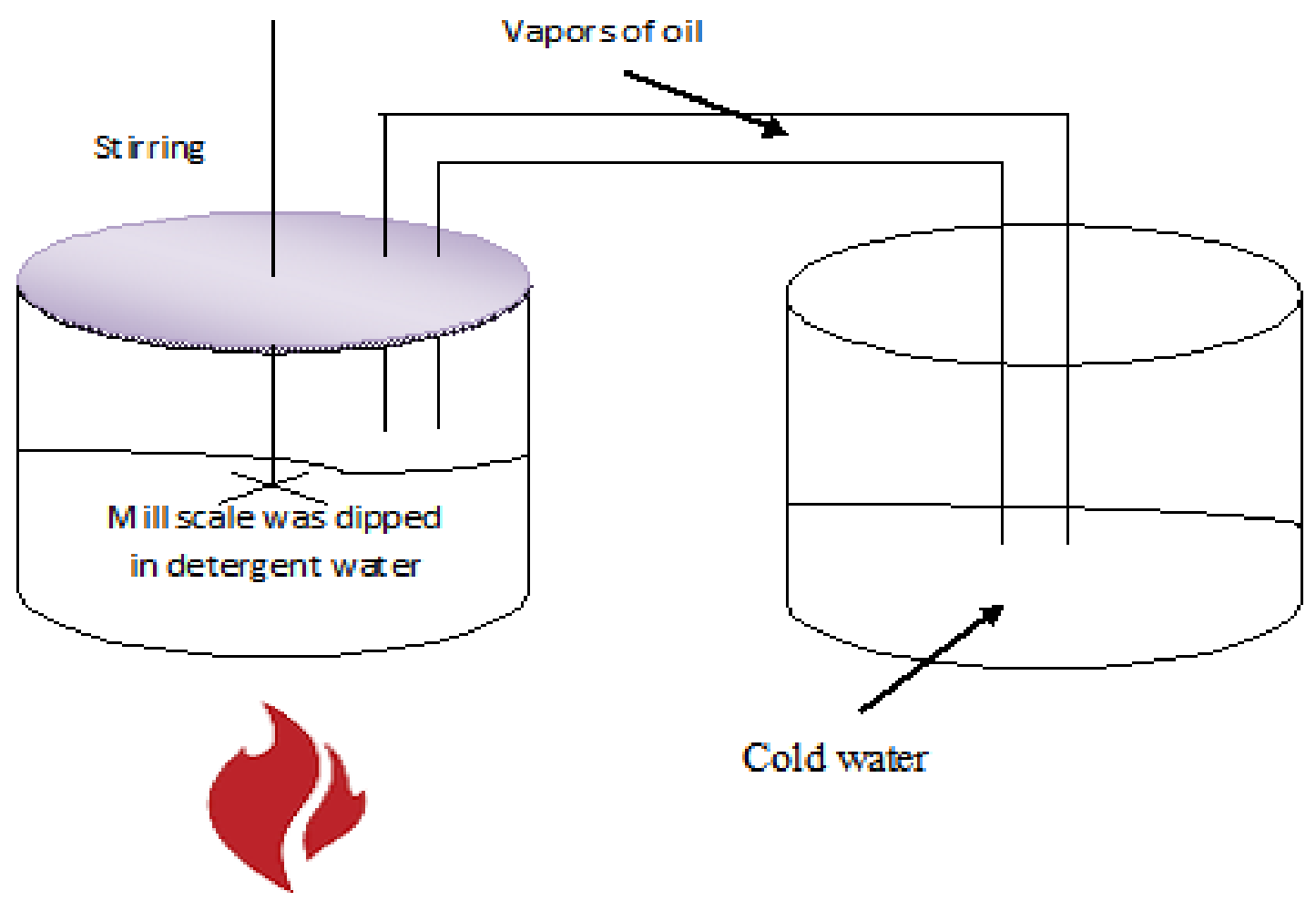

Gas heater

Figure 2. Direct heating of mill scale in detergent containing water.

For further treatment, it was transferred in a covered container (there was no water in the container) attached long pipe (10m long and $0.6 \mathrm{~cm}=0.25$ inches) for collection and condensation of vapors of oil, the other end of pipe is attached to a closed vessel with water both vessels were completely covered. Container containing the washed mill scale puts on the stove 
for continues 30 minutes heating. The Pipe is tightly attached to container and vessel to avoid the chance of toxic emission of oil vapors. After heating oil was found in pipes, water of a vessel and on the inner part lid of the container in which mill scale is heating. No vapor of oil was escaped in the atmosphere and oil vapors were trapped in pipes, water of a vessel and on the inner part lid of container (Figure 3). Residues were dried and collect for chemical tests.

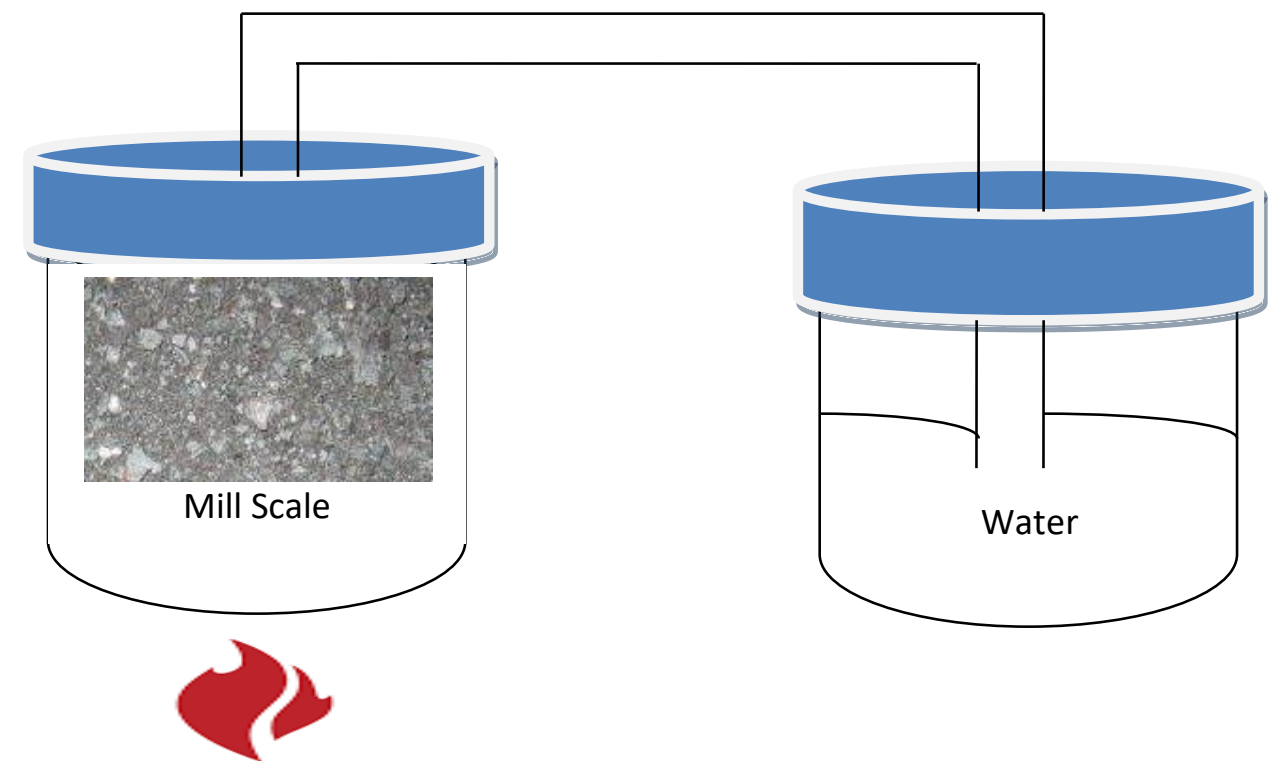

Gas heater

Figure 3. Direct heating of mill scale (after washing with boiling water of detergent) and trapping of oil in long pipe and in a closed container.

\subsection{Solvent extraction}

Mill scale $(500 \mathrm{~g})$ and $n$-hexane $(200 \mathrm{ml})$ were mixed with continued shaking for 15 minutes with stirring as same arrangement in Figure 2 and 3 without heating. The oil was mixed with $n$-hexane, solvent ( $n$-hexane) was decanted carefully because iron particle were also poured out with solvent due to very small size. This process was repeated three times and $200 \mathrm{ml} \mathrm{n}$ hexane were taken every time. The solvent from the extract was recovered by rotary evaporator (BUCHI, Germany) under reduced pressure. After three washings with organic solvent in the last 
for removal of water soluble impurities and mud, water (2.5 liter) was mixed with mill scale. After mixing with continued stirring, the water was decanted. Both decant sample of organic solvent and water were filtered, in filtrate iron is also present with oil and mud, so it was left to dry in the sunlight, then iron was separated by forming layer, iron was in the lower layer. Residues were dried and collect for chemical tests.

Multiple series operation of Phase separation with surfactants in boiling water: In this process mill scale $(500 \mathrm{~g})$ and detergent $(10 \mathrm{~g})$ were mixed in water (2.5 liter) then heat on a gas stove with continued stirring or vibrating for 30 minutes. The decant water was filtered, in decant iron is also present with mud, so it left dry in the sunlight, mud and iron were separated by forming two layers, the upper layer was consist of mud while the iron was in the lower layer. This process was repeated five times, every time fresh water and detergent was taken. During this process large amount of oil and mud separate from mill scale. Residues were dried and collect for chemical tests.

\subsection{Chemical Test}

After drying all samples were sent to Pakistan Steel Process laboratories (ISO9001:2008 Certified) with report numbers PS/PL/2203/ISR-494/2015 dated 18-12-2015 and PS/PL/2203/ISR-505/2016 dated 11-01-2016. Percentage of oil and percentage of iron were determined. Reports from the lab were compared with use of time, energy and number of treatment for the selection of best method.

\subsection{Preparation of Microbial Fuel Cells}

After washing of mill scale detergent containing waste water, which is poisonous for environment, is needed to treatment, manufacturing of microbial fuel cell is environmentally friendly process for utilization of this waste water. By adding of waste food, Waste cooking oil, 
waste fruit, leaf and flower in the waste water converted into fermentable mixture which is capable to produce electricity by the bacterial action.

In double chamber MFCs waste bottle of mineral water (6 lit.) was connected by a salt bridge as shown in Figure 4. For the preparation of salt bridge, a mixture of salica and salt (1:2) were mixed in beaker after this mixture were placed in plastic pipe and end of pipe were closed with clothes pieces with help of a solution this cloth act as semi permeable membranes, dimension of salt bridge is 1 inch x 6 inch. Dimension of electrode is $4 \mathrm{~cm} \mathrm{X} 2 \mathrm{~cm} \mathrm{X} 3.3 \mathrm{~cm}=26.4$ X $10^{-6} \mathrm{~m}$. In anode chamber Zinc was placed with waste materials $(1 \mathrm{Kg})$ in waste water (4 lit) and in the cathode chamber various metal electrodes including Copper. Anode and cathode chambers were connected by salt bridge. Performance of MFCs was checked by measuring of currents and voltages by multimeter. During fermentation and anaerobic digestion of organic waste in waste water produce biogas in anode chamber which were collected by balloon tightly attached with the cap of anode chamber as shown in Figure 4.

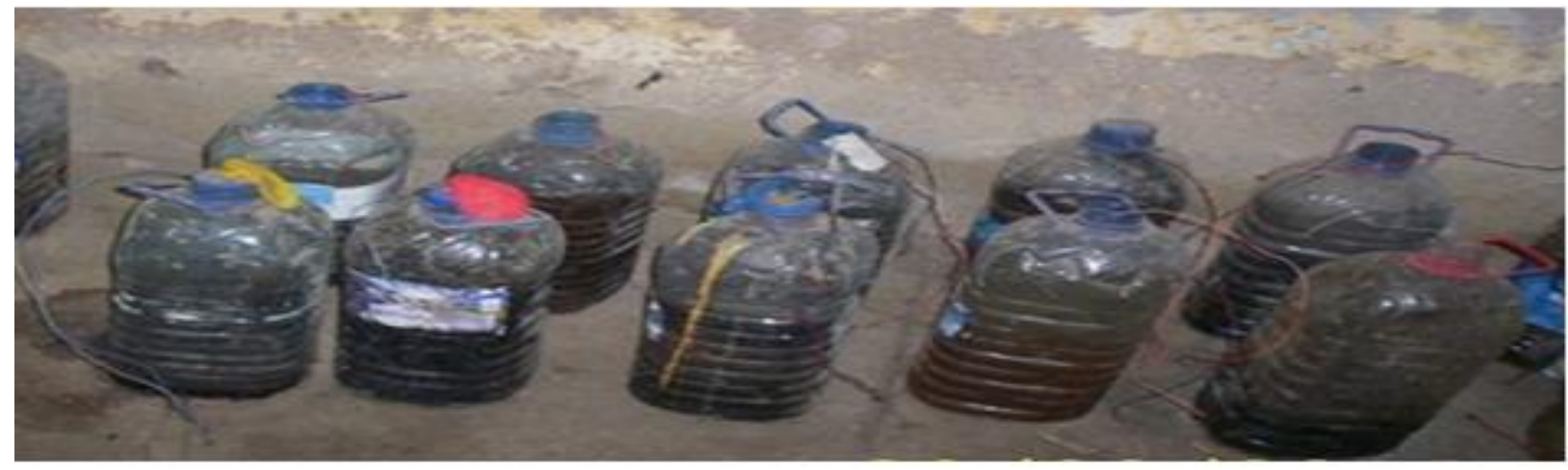

Figure 4. Microbial Fuel Cells for the treatment of wastewater and production of bioelectricity and biogas

\section{Utilization of remaining of waste from MFCs}

After the utilization of MFCs, the remaining organic waste was divided into two portions (1) Filtrates (2) Residue. 


\subsection{The production of biodiesel}

Filtrates were used to produce bioethanol through the partial anaerobic underground fermentation, bioethanol were converted into ethyl benzoate and confirmed by boiling point and chemical test. To increase the yield of bioethanol, water extracts were hydrolyzed. The water extract $(500 \mathrm{ml})$ was taken in an Erlenmeyer flask and treated with $10 \%$ $\mathrm{NaOH}$ with reflux on water bath for 4 hours. The concentrated water extract was taken in a glass bottle (2 liters capacity) followed by yeast (Saccharomyces cerevisiae, $50 \mathrm{~g}$ ). The $\mathrm{pH}$ of the solution was adjusted 6.9 with the addition of $\mathrm{H}_{2} \mathrm{SO}_{4}$ and $\mathrm{NaOH}$. The sealed bottle was placed underground (1.5 feet deep) for a week to achieve the partial anaerobic fermentation. Newly prepared bioethanol was converted to ethyl benzoate. After the fermentation, the fermented mixtures were transferred in an Erlenmeyer flask containing benzoic acid (50 g) and conc. Sulphuric acid $(5 \mathrm{ml})$. The reaction mixture was refluxed for two hours with the help of a water bath $\left(100^{\circ} \mathrm{C}\right)$ and then allowed to cool down at room temperature.

Now, the ethyl benzoate was extracted by solvent-solvent extraction technique. The solvent mixture, $n$-hexane : ethyl acetate $(200 \mathrm{ml}: 200 \mathrm{ml})$ and reaction mixture were taken in the separating funnel and shaken well. The upper organic layer was separated and concentrated by rotary evaporator under reduced pressure. The concentrated ethyl benzoate was purified by column chromatography using $n$-hexane as the mobile phase; ethyl benzoate is used to calculate the amount of ethanol and glucose in different samples. Its purity was further confirmed by boiling point determination by using high temperature Pyrex test tube. The formation of ethyl benzoate was further confirmed by a chemical test, for chemical confirmation ethyl benzoate, which was purified by column chromatography react with $\mathrm{NaHCO}_{3}$. Benzoic acid on warming with sodium hydrogen carbonate gave brisk effervescence of $\mathrm{CO}_{2}$ gas while 
ethyl benzoate did not respond to this test according to the chemical equation as shown in Figure

5.<smiles>O=C(O)c1ccccc1</smiles>

Benzoic acid $\frac{\mathrm{C}_{2} \mathrm{H}_{5} \mathrm{OH}, \mathrm{H}_{2} \mathrm{SO}_{4} \text { (conc.) }}{\text { Reflux }\left(100{ }^{\circ} \mathrm{C}\right), 2 \text { hours }}$

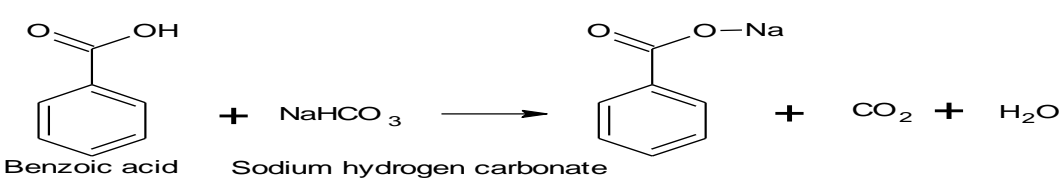

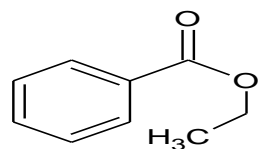

Ethyl benzoate
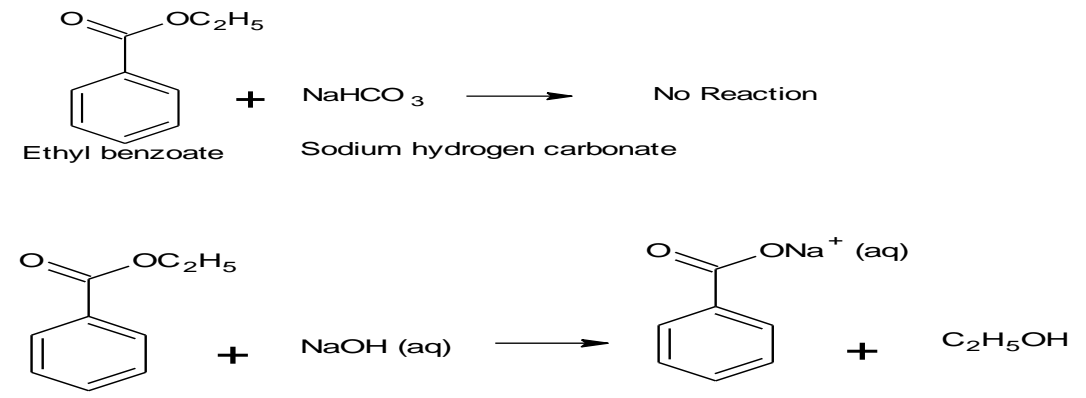

Ethyl benzoate Sodium hydroxide

Sodium benzoate

Ethyl alcohol<smiles>O=C(O[Al+2])c1ccccc1</smiles>

Sodium benzoate

Hydrochloric acid

Benzoic acid Sodium chloride

Figure 5. Chemical equations representing the preparation of ethyl benzoate from a fermented mixture containing freshly prepared bioethanol, chemical test of the derivative of bioethanol (ethyl benzoate)with $\mathrm{NaHCO}_{3}$ and another test of ethyl benzoate conversion into benzoic acid.

\subsection{The production of biodiesel}

For the production of biodiesel, remaining (residue) from MFC contain oil content because in MFCs foods waste, garden waste (waste fruit, leaf and flower) and waste cooking oil were used, the oily content of residue was extracted by $n$-hexane ( 2 liters for every extraction from each MFC). The process of extraction was repeated thrice. The solvent from the extract was recovered by rotary evaporator under reduced pressure. Both methanolysis and ethanolysis have been performed. Oil $(1 \mathrm{~g})$, methanol or ethanol $(15 \mathrm{ml})$ and concentrated $\mathrm{HCl}(0.5 \mathrm{ml})$ or $\mathrm{NaOH}$ 
$(10 \%, 5 \mathrm{ml})$ were taken in the flask and refluxed for 6 hours on the hot plate. After refluxing, the reaction mixture was allowed to cool down at room temperature after that water and $n$-hexane were added and mixed very well. The water layer and organic solvent layer were separated by separating funnel. Biodiesel was separated in $n$-hexane layer whereas in basic hydrolysis glycerol and soap were separated in the water layer.

\subsection{The production of bio-fertilizer}

The residue was used as fertilizer and it was proved as a good fertilizer. The $\mathrm{pH}$ was adjusted with the help of $\mathrm{KOH}, \mathrm{H}_{3} \mathrm{PO}_{4}$ and $\mathrm{HNO}_{3}$. To see the performance of fertilizer, the okra seeds (4 seeds in each pot) were sowed in six different pots and regularly watering all pots every day. All pots were placed under green house for two weeks with regular monitoring for the progress of the plant. A pot was prepared for reference (without any fertilizer). Therefore, both pots were prepared and investigated for the growth of okra. The experiment was monitored daily with the regular provision of water. Similar conditions were provided for both pots throughout the period. During the experimental days, the average temperature was $25^{\circ} \mathrm{C}$. Over 4 days, plants were started to germinate, which carefully noted for comparison and further study. The appearance of plants, size of stem and leaf were measured regularly. Observations were compared and performance of fertilizer prepared from the waste of MFC was investigated. The whole processes have been done to fulfill the approach of zero waste management as shown in Figure 6. 


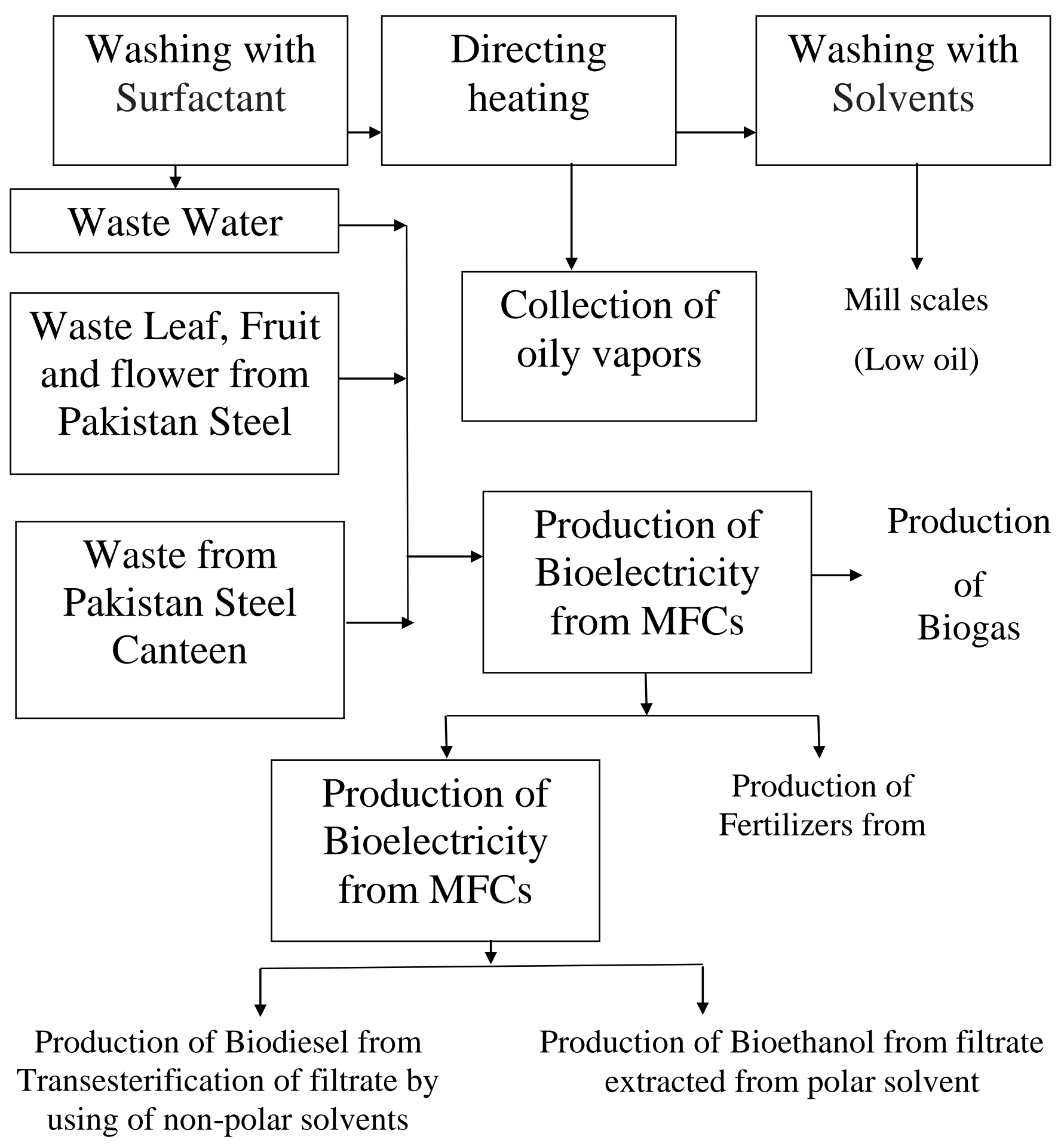

Figure 6. Scheme for the treatment of mill scales 


\section{Result and Discussion}

\subsection{Pretreatment and separation of iron from mill scale}

Different methods were used to separate oil from mill scale and possibilities for success will deliberate. By comparing all the methods, a suggestion will be given for the best method with respect to yield, low cost and suitable for environmental, described in Table 1. Methods will be studied in the laboratory and suggestions will be given for industrials uses.

Table 1. Comparison of different methods of oil separation from mill scale.

\begin{tabular}{|c|c|c|c|c|c|}
\hline $\begin{array}{l}\text { S. } \\
\text { No. }\end{array}$ & Name of methods & $\begin{array}{l}\text { Percentage } \\
\text { of oil }\end{array}$ & $\begin{array}{l}\text { Percentage of iron } \\
\text { after treatment }\end{array}$ & $\begin{array}{l}\text { Number of } \\
\text { washing }\end{array}$ & $\begin{array}{l}\text { Time for each } \\
\text { heat treatment }\end{array}$ \\
\hline 1. & Original sample & 13.20 & 52.60 & - & - \\
\hline 2. & $\begin{array}{l}\text { Washing with surfactants, heating } \\
\text { and collection of oil with long pipe }\end{array}$ & 01.10 & 60.46 & 3 & 30 minutes \\
\hline 3. & Solvent extraction & 4.12 & 54.77 & 2 & - \\
\hline 4. & $\begin{array}{l}\text { Multiple series operation of Phase } \\
\text { separation by boiling water with } \\
\text { surfactants }\end{array}$ & 5.09 & 58.56 & 6 & 30 minutes \\
\hline
\end{tabular}

\subsection{Pretreatment of wastewater and waste}

Filtrate of MFC was used for fermentation for the preparation of bioethanol, fermented mixture was used for the preparation of ethyl benzoate after purified by column chromatography, collected ethyl benzoate was carefully measured then by using stoichiometry ethanol and glucose were calculated as described in Table 2. From table showed it is shown that different sample of waste matter, including waste food, waste cooking oil, waste fruit, leaf and flower contain 5 to 6 percentage of fermentable glucose while other polysaccharides will be more than this $6 \%$ as shown in Table 3. 
Table 2. Different parameters of MFC

\begin{tabular}{cccccc}
\hline $\begin{array}{c}\text { No. of } \\
\text { Cell }\end{array}$ & $\begin{array}{c}\text { Current } \\
(\mu \text { Amp })\end{array}$ & $\begin{array}{c}\text { Current } \\
\text { density } \\
\left(\mathrm{Amp} / \mathrm{m}^{3}\right)\end{array}$ & Volt (m.volt) & Power (watt) & $\begin{array}{c}\text { Power density } \\
\left(\mathrm{m} . \mathrm{watt}^{3}\right)\end{array}$ \\
\hline 1. & 1284.84 & 48.67 & 484 & $6.22 \times 10^{-4}$ & 23.55 \\
2. & 1116.5 & 42.29 & 655.5 & $7.32 \times 10^{-4}$ & 27.72 \\
3. & 1842.9 & 69.78 & 572.88 & $1.06 \times 10^{-3}$ & 39.99 \\
4. & 863.50 & 32.71 & 840.34 & $7.25 \times 10^{-4}$ & 27.49 \\
5. & 792.39 & 30.01 & 986.28 & $7.82 \times 10^{-4}$ & 29.6 \\
6. & 1203.38 & 45.58 & 834.22 & $1.00 \times 10^{-4}$ & 38.02 \\
\hline
\end{tabular}

Table 3. Detail of glucose, ethanol and ethyl benzoate achieved from different samples of $1 \mathrm{Kg}$ waste

\begin{tabular}{ccccc}
\hline $\begin{array}{c}\text { Filtrate of cell } \\
\text { number }\end{array}$ & Ethyl benzoate $(\mathrm{g})$ & Ethanol $(\mathrm{g})$ & Glucose $(\mathrm{g})$ & Percentage of glucose \\
\hline 1. & 80.00 & 24.52 & 47.96 & \\
2. & 88.88 & 27.24 & 53.30 & 5.796 \\
3. & 104.96 & 32.18 & 62.96 & 6.296 \\
4. & 88.88 & 27.24 & 53.30 & 5.330 \\
5. & 96.38 & 29.56 & 57.84 & 5.784 \\
6. & 100.24 & 30.74 & 60.14 & 6.014 \\
\hline
\end{tabular}

\subsection{Production of biodiesel from waste water and waste}

Biodiesel were produced by both methanolysis and ethanolysis. Oil (4 g), ethanol (25 $\mathrm{ml})$ or methanol $(25 \mathrm{ml})$ and concentrated $\mathrm{HCl}(2.5 \mathrm{ml})$ or $\mathrm{NaOH}(10 \%, 10 \mathrm{ml})$ were taken in the flask and refluxed for 6 hours on a hotplate. After refluxing, the reaction mixture was allowed to cool down then water and $n$-hexane were added and mixed. The water layer and organic layer were separated by separating funnel. Biodiesel was separated in $n$-hexane layer, whereas glycerol and soap (only in basic hydrolysis) were separated in the water layer [19]. Yield of Fatty Acid Methyl Ester (FAME) and Fatty Acid Ethyl Ester (FAEE) were calculated as shown in Table 4.

Table 4. Different techniques of biodiesel production

\begin{tabular}{|c|c|c|c|c|c|c|}
\hline \multirow{2}{*}{$\begin{array}{c}\text { Filtrate of } \\
\text { cell } \\
\text { number }\end{array}$} & \multirow[t]{2}{*}{$\begin{array}{l}\text { Method used for } \\
\text { tranesterification }\end{array}$} & \multirow[t]{2}{*}{$\begin{array}{l}\text { Oil extracted } \\
(\mathrm{gm})\end{array}$} & \multicolumn{2}{|c|}{$\begin{array}{c}\text { Yield of } \\
\text { Biodiesel (\%) } \\
\end{array}$} & \multirow[t]{2}{*}{$\begin{array}{c}\text { Glycerol } \\
(\%)\end{array}$} & \multirow[t]{2}{*}{ Soap (\%) } \\
\hline & & & FAME & $\overline{\text { FAEE }}$ & & \\
\hline \multirow[t]{2}{*}{1.} & Acidic & 16.0 & 32.6 & 35.6 & 6.5 & Nil \\
\hline & Basic & & 34.4 & 36.2 & 4 & 5.5 \\
\hline \multirow[t]{2}{*}{2.} & Acidic & 17.0 & 35.0 & 36.8 & 7.0 & Nil \\
\hline & Basic & & 36.0 & 38.6 & 5.0 & 5.8 \\
\hline \multirow[t]{2}{*}{3.} & Acidic & 22.2 & 38.8 & 39.7 & 7.3 & Nil \\
\hline & Basic & & 41.2 & 40.8 & 6.5 & 7.3 \\
\hline 4. & Acidic & 18.0 & 37.5 & 38.7 & 7.4 & Nil \\
\hline
\end{tabular}




\begin{tabular}{lcccccc} 
& Basic & & 38.7 & 39.8 & 5.5 & 6.2 \\
6. & Acidic & 18.2 & 38.5 & 39.4 & 8.0 & Nil \\
6. & & 39.6 & 40.4 & 6.2 & 7.4 \\
& Basic & & 38.4 & 39.2 & 7.3 & Nil \\
\hline Acidic & 23.0 & 38.0 & 40.4 & 6.6 & 7.4 \\
\hline
\end{tabular}

\subsection{Production of biogas from waste water and waste}

In the anodic chamber, wastewater samples and other waste were mixed together and placed under partial anaerobic condition (anode chamber will be closed). With the passage of time biogas was produced due to the biodegradation which was collected in balloons and its volume was determined by using the thread and scale as shown in Table 5.

Table 5. Amount of biogas evolved from anode chamber of different MFCs.

\begin{tabular}{cc}
\hline Filtrate of cell number & Biogas volume $\left(\mathrm{cm}^{3}\right)$ \\
\hline 1. & 410 \\
2. & 444 \\
3. & 490 \\
4. & 444 \\
5. & 470 \\
6. & 485 \\
\hline
\end{tabular}

\subsection{Production of fertilizers from waste water and waste}

Wastewater sample, mixed with waste from MFCs, was collected and then left this mixture for a week. Now, $\mathrm{pH}$ of all the mixtures was checked and maintained at 6 to 7 with $\mathrm{KOH}, \mathrm{HNO}_{3}$ and $\mathrm{H}_{3} \mathrm{PO}_{4}$. In most of the pots, seeds were started to germinate after 4 days. However, growth was not appeared in the reference pot. Progress in the growth of plants was investigated by measuring the size of the stem and leaves as shown in Table 6.

Table 6. Performance of biofertilizer produced from the remaining of MFCs.

\begin{tabular}{|c|c|c|c|}
\hline Residue of cell number & First appearance of plant & Size of leaf (mm/day) & Size of stem (mm/day) \\
\hline 1. & $5^{\text {th }}$ day & 0.833 & 1.042 \\
\hline 2. & $5^{\text {th }}$ day & 0.932 & 1.142 \\
\hline 3. & $5^{\text {th }}$ day & 1.043 & 1.324 \\
\hline 4. & $5^{\text {th }}$ day & 0.932 & 1.142 \\
\hline 5. & $5^{\text {th }}$ day & 0.986 & 1.222 \\
\hline 6. & $5^{\text {th }}$ day & 1.153 & 1.313 \\
\hline
\end{tabular}




\subsection{Treatment of waste oil (Lubricant)}

Mill scale was treated in a covered container attached with long pipe for collection and condensation of vapors of oil, the other end of pipe was attached to a closed vessel with water both vessels were completely covered. Container containing the mill scale was put on stove; a pipe was tightly attached with container to avoid the chance of toxic emission of oil vapors. After heating oil (lubricant) was trapped in pipe, in container and on the inner part lid of the container in which mill scale was heating. This oil may be treated for pyrolysis at this stage pyrolysis which will be very feasible.

\section{Conclusions and Recommendations}

In this research economical, environment friendly and zero waste management approach were used to recover of iron from mill scale. Metallurgy and Environmental engineering were successfully used and a new approach was introduced. This work was started for separation of oil and recovery of iron from mill scale, but after washing a large amount of wastewater was collected which contain toxic materials for the environment. Therefore, for the protection of environment and treatment of this wastewater, some additional steps have taken. By mixing of some common waste (waste food, waste cooking oil, waste fruit, leaf and flower) those commonly found in our environment were used with waste water for the production of bioelectricity, bioethanol, biogas, biodiesel and biofertilizer. This is an effort to combination and use of Environmental engineering and Metallurgical engineering which is a requirement of our future, so this research will be a mile stone for future research.

\section{References}

[1] Umadevi, T.; Brahmacharyulu, A.; Karthik, P.; Ranjan, M. Recycling of steel plant mill scale via iron ore sintering plant. Ironmak Steelmak. 2012, 39(3), 222-227. 
[2] Gaballah, N. M.; Zikry, A. F.; Khalifa, M. G.; Farag, A. B.; El-Hussiny, N. A.; Shalabi, M. E. H. Production of Iron from Mill Scale Industrial Waste via Hydrogen. OJINM. 2013, 3(3), 23-28.

[3] M. A. Legodi; de Waal, D. The preparation of magnetite, goethite, hematite and maghemite of pigment quality from mill scale iron waste. Dyes and Pigments. 2007, 74(1), 161-168.

[4] De Beer, J. Book with title of Potential for Industrial Energy-Efficiency Improvement in the Long Term, Eco-Efficiency in Industry and Science.Vol. 5, Springer Netherlands, 2000, 93166.

[5] Lopez, F.A.; Martin, M.I.; Perez, C.; Lopez-Delgado, A.; Alguacil, F.J. Removal of copper ions from aqueous solutions by a steel-making by-product. Water Res. 2003, 37(16), 3883-3890.

[6] Gomez, E.; Rani, D. A.; Cheeseman, C. R.; Deegan, D.; Wise, M.; Boccaccini, A. R. Thermal plasma technology for the treatment of wastes: A critical review. J. Hazard Mater. 2009, 161(2-3), 614-626.

[7] Spengler, Th.; Püchert, H.;Penkuhn, T.; Rentz, O. Environmental integrated production and recycling management. Eur. J. Oper. Res. 1997, 972(2) 308-326

[8] Blake, N. R.; Siefert, K. S. Process for de-oiling mill scale. US5047083 A.

[9] Eissa, M.; Ahmed, A.; El-Fawkhry, M. Conversion of Mill Scale Waste into Valuable Products via Carbothermic Reduction. J. of Metallurgy. 2015. 
[10] Yasar, A.; Haider, R.; Tabinda, A. B.; Kausar, F.; Khan, M. A. Comparison of Engineering Emission from Heavy, Medium and light Vehicle from CNG Diesel and Gasoline Fuels. Pol. J. Environ. Stud. 2013, 22(4), 1277-1281.

[11] Fox, R. D, Physical/chemical treatment of organically contaminated soils and sediments. $J$ Air Waste Manag Assoc. 1996, 46(5), 391-413.

[12] Muir, D. C. G.; Howard, P. H. Are there other persistent organic pollutants? A challenge for environmental chemists. Environ. Sci. Technol. 2006, 40 (23), 7157-7166.

[13] Twigg, M. V. Progress and future challenges in controlling automotive exhaust gas emissions. Appl. Catal. B. 2006, 70 (1-4), 2-15.

[14] Dewil, R.; Appels, L.; Baeyens, J. Energy use of biogas hampered by the presence of siloxanes. J. Energ Convers Manage. 2006, 47 (13-14), 1711-1722.

[15] Natalie R. B.; Kristine, S. S. Process for de-oiling mill scale. US5047083 A, 1991.

[16] Abel, P. D.; Toxicity of synthetic detergents to fish and aquatic invertebrates. J. Fish Biol, 1974, 6(3), 279-298.

[17] Zhiqiang, Y. U. Advances in Microbial Remediation on the Application of Heavy Metal Pollution in Agricultural Water Resources. J. Agr. Sci. Tech. 2015, 16(12), 2824-2828.

[18] Hussain, M. S.; Ph.D thesis, FUUAST University, Karachi, 2016. 